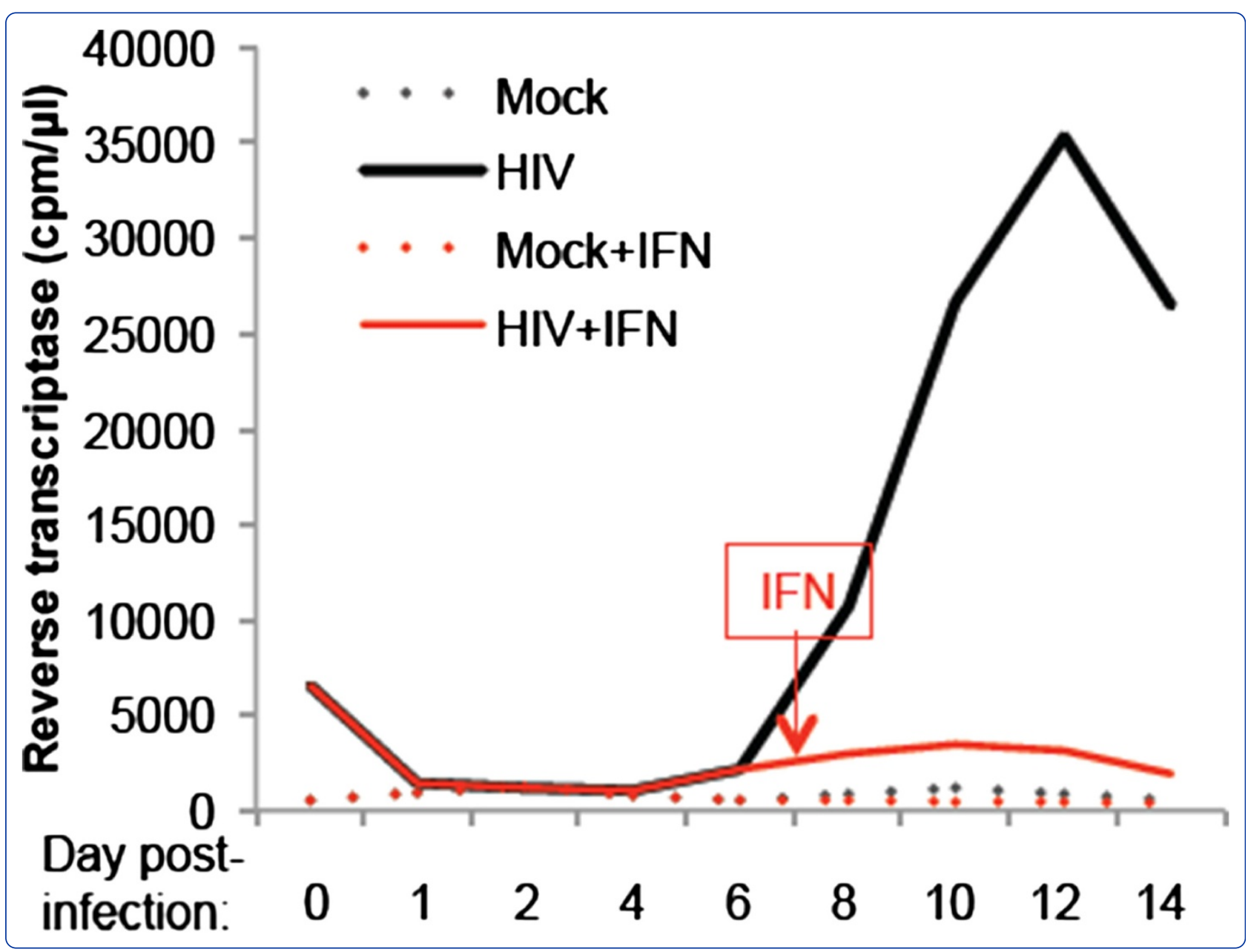

The PKR activator, PACT, becomes a PKR inhibitor during HIV-1 replication

Clerzius et al.

C BioMed Central 


\title{
RESEARCH
}

Open Access

\section{The PKR activator, PACT, becomes a PKR inhibitor during HIV-1 replication}

Guerline Clerzius $^{1,2,6+}$, Eileen Shaw ${ }^{1,2+}$, Aïcha Daher ${ }^{1 \dagger}$, Samantha Burugu ${ }^{1,3}$, Jean-François Gélinas ${ }^{1,3,7}$, Thornin Ear ${ }^{1,2}$, Lucile Sinck ${ }^{1,2}$, Jean-Pierre Routy ${ }^{2,4}$, Andrew J Mouland ${ }^{1,2,3}$, Rekha C Patel ${ }^{5}$ and Anne Gatignol ${ }^{1,2,3^{*}}$

\begin{abstract}
Background: HIV-1 translation is modulated by the activation of the interferon (IFN)-inducible Protein Kinase RNA-activated (PKR). PKR phosphorylates its downstream targets, including the alpha subunit of the eukaryotic translation Initiation Factor 2 (elF2a), which decreases viral replication. The PKR Activator (PACT) is known to activate PKR after a cellular stress. In lymphocytic cell lines, HIV-1 activates PKR only transiently and not when cells replicate the virus at high levels. The regulation of this activation is due to a combination of viral and cellular factors that have been only partially identified.
\end{abstract}

Results: PKR is transiently induced and activated in peripheral blood mononuclear cells after HIV-1 infection. The addition of IFN reduces viral replication, and induces both the production and phosphorylation of PKR. In lymphocytic Jurkat cells infected by HIV-1, a multiprotein complex around PKR contains the double-stranded RNA binding proteins (dsRBPs), adenosine deaminase acting on RNA (ADAR) 1 and PACT. In HEK 293T cells transfected with an HIV-1 molecular clone, PACT unexpectedly inhibited PKR and elF2a phosphorylation and increased HIV-1 protein expression and virion production in the presence of either endogenous PKR alone or overexpressed PKR. The comparison between different dsRBPs showed that ADAR1, TAR RNA Binding Protein (TRBP) and PACT inhibit PKR and elF2a phosphorylation in HIV-infected cells, whereas Staufen1 did not. Individual or a combination of short hairpin RNAs against PACT or ADAR1 decreased HIV-1 protein expression. In the astrocytic cell line U251MG, which weakly expresses TRBP, PACT mediated an increased HIV-1 protein expression and a decreased PKR phosphorylation. In these cells, a truncated PACT, which constitutively activates PKR in non-infected cells showed no activity on either PKR or HIV-1 protein expression. Finally, PACT and ADAR1 interact with each other in the absence of RNAs.

Conclusion: In contrast to its previously described activity, PACT contributes to PKR dephosphorylation during HIV-1 replication. This activity is in addition to its heterodimer formation with TRBP and could be due to its binding to ADAR1. HIV-1 has evolved to replicate in cells with high levels of TRBP, to induce the expression of ADAR1 and to change the function of PACT for PKR inhibition and increased replication.

Keywords: Human immunodeficiency virus type 1 (HIV-1), Protein kinase RNA-activated (PKR), PKR activator (PACT), Eukaryotic translation initiation factor 2 (elF2a), Lymphocytes, Astrocytes

\footnotetext{
* Correspondence: anne.gatignol@mcgill.ca

${ }^{\dagger}$ Equal contributors

'Lady Davis Institute for Medical Research, 3999 Côte Ste Catherine,

Montréal, QC H3T 1E2, Canada

${ }^{2}$ Department of Medicine, Division of Experimental Medicine McGill

University, Montréal, Québec, Canada

Full list of author information is available at the end of the article
}

\section{Biomed Central}

(c) 2013 Clerzius et al.; licensee BioMed Central Ltd. This is an Open Access article distributed under the terms of the Creative Commons Attribution License (http://creativecommons.org/licenses/by/2.0), which permits unrestricted use, distribution, and reproduction in any medium, provided the original work is properly cited. 


\section{Background}

Human immunodeficiency virus type 1 (HIV-1) mRNA expression is controlled at the transcriptional, processing and translational levels [1-3]. The main translational mechanism is a cap-mediated scanning from its 5 ' end but additional mechanisms occur including internal ribosome entry site in gag, programmed -1 ribosomal frameshift to produce Gag-Pol and discontinuous ribosome scanning to translate Env [4-6]. HIV-1 translation is modulated by viral components, like Trans-Activation Response element (TAR) RNA [7-10] and by cellular factors including translation factors, Protein Kinase RNA activated (PKR), TAR RNA Binding Protein (TRBP), PKR Activator (PACT), the La autoantigen, Staufen1 and the Adenosine Deaminase Acting on RNA (ADAR)1 [9,11-15]. The positive factors act by releasing the block due to the TAR structure, by inhibiting PKR or by inhibiting PACT [7-9,16-20].

The interferon (IFN)-inducible PKR is a key doublestranded RNA-binding protein (dsRBP), and a serine/threonine kinase. Its activation leads to autophosphorylation and the phosphorylation of its downstream targets, including the alpha subunit of the eukaryotic translation initiation factor 2 (eIF2 $\alpha$ ). Phosphorylated eIF2 $\alpha$ (P-eIF2 $\alpha$ ) prevents translational initiation of viral and cellular mRNAs. PKR is central in the host innate defense strategies with strong antiviral and antigrowth activities [21-24]. In addition, its $\mathrm{N}$-terminus forms a complex with proteins involved in cellular signaling pathways to mediate the activation of the NF- $\mathrm{kB}$ protein complex, which contributes to the induction of inflammatory cytokines $[25,26]$. PKR is extremely effective in restricting HIV-1 expression and replication in vitro [12,19,27-30]. Despite this observed activity, HIV-1 replicates efficiently in many permissive cell lines and primary cells, suggesting that the kinase activity of PKR in natural infection of lymphocytes is tightly regulated [17].

Many viruses that replicate efficiently have means to inactivate PKR and the HIV-1 Tat protein is one of these countermeasures [31-33]. Cells also avoid PKR activation using dsRNA sequestration or protein-protein interactions, likely as a normal process to allow their growth. Examples of direct interaction include the cellular protein $\mathrm{p} 58^{\mathrm{IPK}}$, which binds to PKR and prevents its dimerization, tRNA-dihydrouridine synthetase-2, TRBP and ADAR1, which bind through their dsRNA Binding Domains (dsRBDs) and exert a strong inhibitory activity [12,19,22,32,34-40]. Besides dsRNA and heparin, PACT, the cytokine MDA-7/interleukin 24 and the transcription factor E2F-1 induce PKR activation [32,41-45]. PKR activation upon virus infection is also observed in some specialized cells. For example, cardiomyocytes are cells with high activation of PKR and PKR-like ER protein kinase (PERK) upon coxsackievirus infection due to a downregulation of $\mathrm{p} 58^{\mathrm{IPK}}$ by the virus [46]. Similarly, astrocytic cells represent an example of naturally HIV-resistant cells with high
PKR activation. In these cells, TRBP is expressed at very low amounts and cannot counteract PKR activation induced by the virus [47-49]. In contrast, in HIV-infected lymphocytes PKR activation is reduced when the virus reaches high concentrations and this is due in parts to the expression of TRBP, ADAR2 and to an increased ADAR1 expression that inhibits PKR activation [12,17,50,51].

PACT and its murine homolog RAX, are stressinducible PKR activators $[42,44,52]$. They are proapoptotic proteins that induce apoptosis upon cellular stress by PKR activation [52-54]. PACT has two dsRBDs and a C-terminus domain called Medipal by homology with TRBP. All three domains in PACT homodimerize and interact with PKR and TRBP $[20,55,56]$. The Medipal domain mediates activation of PKR or inhibition by TRBP [18,55,57-59]. A cellular stress dissociates TRBPPACT interactions and allows PACT activation of PKR. Therefore, PACT acts as a PKR activator in cells with low TRBP concentration or after stress induction, whereas it acts as a PKR inhibitor in cells with high TRBP content $[13,18,20,55,60]$. Its activity has not been tested in HIVinfected cells. Here, we observed that PKR is transiently induced and activated in HIV-1 infected peripheral blood mononuclear cells (PBMCs) with increased expression of both ADAR1 and PACT. We show that PACT binds to PKR during HIV-1 infection and that its activity is changed from an activator into an inhibitor of PKR in HIV-permissive cells and in astrocytic cells, which do not replicate HIV-1 efficiently. This change of function may be related to an interaction between ADAR1 and PACT.

\section{Results}

PKR is transiently induced and activated in PBMCs at the beginning of HIV-1 infection

We have previously shown that HIV-1 infection of the lymphocytic Jurkat $\mathrm{T}$ cell line induces PKR activation during the first days of infection, followed by an inactivation during high HIV-1 replication [12]. To determine if this regulation is also true in primary cells, we infected PBMCs from healthy donors with the pNL4-3 HIV-1 clone (Figure 1). To determine the importance of PKR activation during an IFN response in these cells and its impact on HIV-1 replication, half of the culture was treated with IFN at day 7 and IFN was maintained in the medium up to day 14. Following viral infection, reverse transcriptase (RT) activity was visible at day 6 and reached a peak at day 12 , whereas the addition of IFN at day 7 induced a dramatic decrease in RT activity at day 8 (Figure 1A). Cell samples were gathered every two days and analyzed by Western blotting (Figure 1B). We first observed a very low basal level of PKR in uninfected cells (D0). PKR expression was induced from day 4 to 10 with a higher induction at day 6. It was activated (P-PKR) mainly at day 6 followed by deactivation. In contrast, when IFN was added at day 7 , 


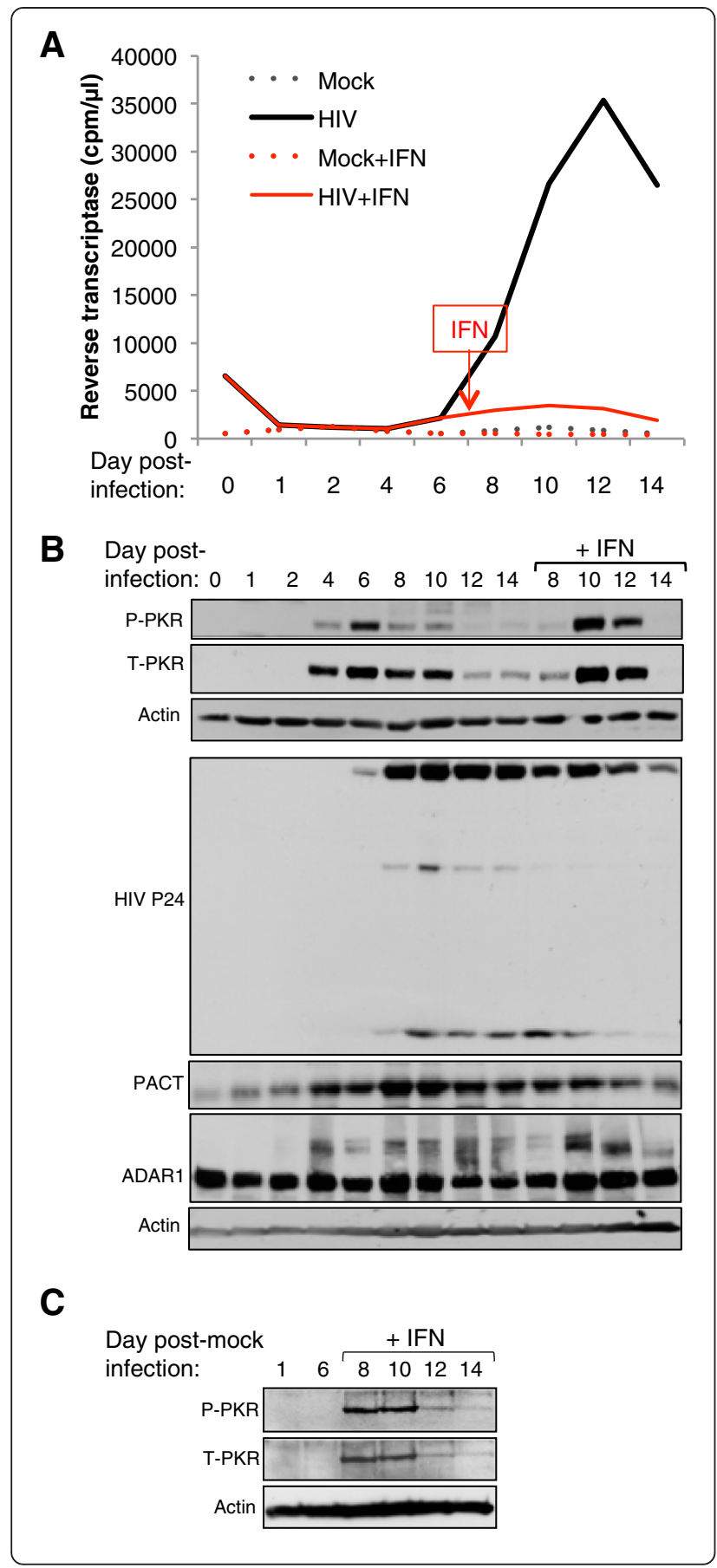

Figure 1 PKR is activated after HIV-1 infection and inhibited during active HIV-1 replication. A) HIV-1 pNL4-3 kinetics from infected PBMCs. $6.5 \times 10^{7}$ PBMCs from a healthy donor were infected with HIV-1 pNL4-3. At day 7, cells were separated in two flasks and IFN $\alpha / \beta(10000 \mathrm{U} / \mathrm{mL})$ was added to the cells in one of them up to day 14 . Aliquots of cell supernatant were collected at different times and assayed for RT activity. B) Protein expression of pNL4-3-infected PBMCs. $50 \mu \mathrm{g}$ of whole-cell extracts from pNL4-3 -infected PBMCs from different harvest times were subjected to a 10\% SDS PAGE and blotted with anti-P-PKR, anti-PKR, anti-HIV-p24, anti-PACT, anti-ADAR1 and anti-actin antibodies as indicated. C) Protein expression of mock-infected PBMCs. $6.5 \times 10^{7}$ PBMCs from the same donor as in B were cultured and passed at the same time as in B. IFN a/ $\beta$ was added similarly from day 7 to $14.50 \mu \mathrm{g}$ of whole-cell extracts from mock-infected PBMCs from the indicated times were subjected to a $10 \%$ SDS PAGE and blotted with anti-P -PKR, anti-PKR and anti-actin antibodies as indicated.

PKR was induced and activated 3 days after (D10-12). Because ADAR1 expression is induced upon HIV-1 infection in Jurkat cells [12], we also evaluated its expression in this experiment. We found that ADAR1 p150 was induced at day 4 and was maintained up to day 14. IFN further induced its expression at day 10. To determine if PACT could likewise have a role in the regulation of PKR during HIV-1 infection of PBMCs, we also evaluated its expression. Surprisingly, we found an increase in PACT expression concomitant with ADAR1 p150 increase just before the expression of Gag protein was visible. In this case, PACT was not further induced by IFN. Interestingly, in a mock infection of the same cells, PKR was induced and activated one day after the addition of IFN (Figure 1C), suggesting that this induction is delayed by two days in HIV-1 infected cells. These results show that, PKR is transiently induced and activated in primary lymphocytes and deactivated when the virus replicates actively and that ADAR1 and PACT may play a role in this regulation.

\section{PACT belongs to a multiprotein complex formed around PKR during HIV-1 infection}

Many viral and cellular factors prevent PKR activation resulting in active viral infections and cell growth $[32,33]$. In the case of HIV-1 infection, the viral protein Tat, large amounts of TAR RNA, cellular proteins TRBP and ADAR1 all contribute to PKR inhibition [17]. Because cells also express PKR activators, and because we observed an increase in PACT expression during HIV-1 infection, we questioned whether PACT could contribute to PKR activation to enhance cell response and balance its inhibition by other factors. We have previously demonstrated that PACT is an activator or an inhibitor of PKR depending on TRBP expression in stressed or non-stressed cells $[18,20,55]$. We also observed that PACT expression is slightly increased at the peak of infection in Jurkat cells (Figure 2, input). We next determined if PACT was present in the complex formed around PKR during HIV-1 


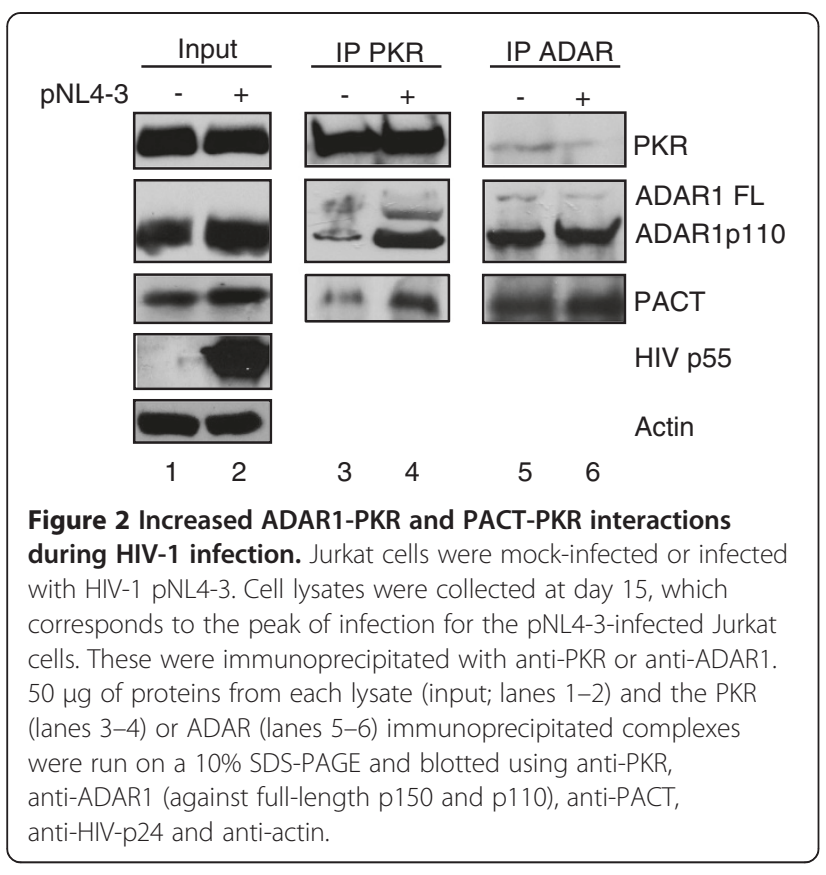

infection of lymphocytes. By immunoprecipitation (IP) with a PKR antibody, we observed that PACT interaction with PKR is increased at the peak of infection (Figure 2). This result resembles the previously observed increase in ADAR1 production and interaction [12]. By IP with an ADAR1 antibody, we also found that PACT is in the same complex as ADAR1, therefore suggesting that these two proteins are part of the multiprotein complex around PKR in HIV-1 infected cells.

\section{PACT is a PKR inhibitor in HIV-1 transfected HEK 293T cells}

We next questioned whether the role of PACT in a complex with PKR during HIV-1 infection would be as an activator or an inhibitor. To determine this role on viral protein expression and virion production, we transfected HEK 293T cells with pNL4-3 in the absence or presence of transfected PKR and evaluated the activity of a PACT expressing vector on viral expression and on PKR activation (Figure 3). Transfection of the HIV-1 molecular clone induced PKR and eIF2 $\alpha$ phosphorylation (Figure $3 \mathrm{~A}$ and $B$, lane 2). When cells were transfected with pNL4-3 and PACT in the absence of overexpressed PKR, PACT was able to increase HIV-1 protein expression and virion production up to 2.3 fold (Figure 3A). Surprisingly, increasing amounts of PACT clearly prevented PKR and eIF $2 \alpha$ phosphorylation, indicating that the protein acts as an inhibitor of endogenous PKR and contributes to the enhancement of HIV-1 translation and consequently to the increased virion production.

As previously observed [12,49], transfected PKR reduced the expression of HIV-1 proteins and viral production and we show here that this is due to the concomitant increase in the ratio between P-PKR and PKR (Figure 3B, lane 3). In this case, increasing amounts of PACT restored viral protein expression and virion production up to 7 fold over the PKR-inhibited RT amount. The large amount of PKR did not allow appropriate quantification of the P-PKR/PKR ratio, but the P-eIF2 $\alpha$ /eIF2 $\alpha$ ratio clearly indicated that low amounts of PACT prevented the phosphorylation of eIF $2 \alpha$ and increasing amounts restored HIV-1 protein expression and virion production (Figure 3B).

\section{PACT, ADAR1 and TRBP inhibit PKR and elF2 $a$} phosphorylation and increase HIV-1 protein expression

To compare the activity of the different dsRBPs that contribute to HIV-1 expression and may inhibit PKR activation in HIV-1-infected cells, we next overexpressed PACT, ADAR1, TRBP and Staufen1 with pNL4-3 in the absence or presence of transfected PKR (Figure 4). When PKR was not overexpressed, all four proteins induced a mild increase of HIV-1 protein expression and virion production reflected by HIV-1 p24 expression in cells and RT assay in the supernatant (Figure 4A). In this assay, a dramatic difference was observed in PKR and eIF2 $\alpha$ phosphorylation between the four dsRBPs. PACT, ADAR1 and TRBP completely inhibited PKR and eIF2 $\alpha$ phosphorylation, whereas Staufen1 only induced a modest reduction, suggesting that the first three dsRBPs increase virus expression mainly by acting on PKR, whereas Staufen1 increases virus production by a PKR-independent mechanism. When PKR was overexpressed, PACT, ADAR1 and TRBP restored PKR-inhibited HIV-1 expression and virion production, but Staufen1 did not (Figure 4B). The level of HIV-1 p24 expression reflected a complete restoration of viral protein expression with PACT, ADAR1 and TRBP, but only a low increase by Staufen 1 over PKR inhibition. The P-PKR/PKR and the P-eIF $2 \alpha /$ eIF $2 \alpha$ ratio were difficult to evaluate due to the high expression of transfected PKR, but suggests that PACT, ADAR1 and TRBP induce an additional mechanism, which also contributes to the restoration of viral expression in the context of overexpressed PKR.

shRNAs against PACT and ADAR1 inhibit HIV-1 expression To further determine the role of endogenous PACT on HIV-1 expression and to compare with the function of ADAR1, we generated short hairpin RNAs (shRNAs) against PACT and against ADAR1 mRNAs to decrease their protein expression (Figure 5). Cotransfection of HEK 293T cells with pNL4-3 together with the shRNA1 or 2 against PACT (P1 and P2, two variants of the same sequence), the shRNA against ADAR1 or a combination of shRNA ADAR1 and shRNA P2 against PACT all decreased HIV-1 protein expression and viral production. 

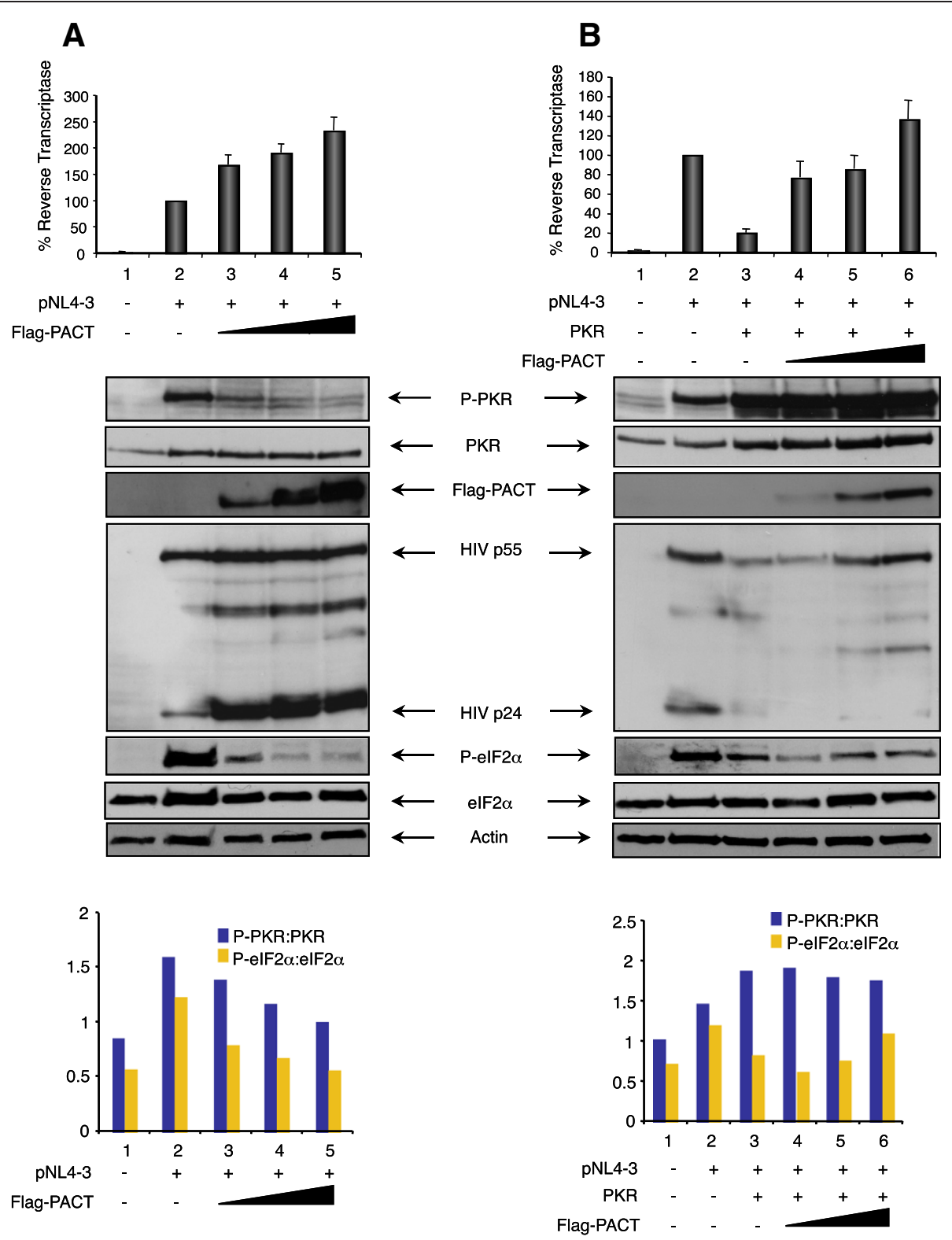

Figure 3 PACT increases HIV-1 protein expression and virion production in HEK 293T cells by PKR and elF2a inhibition. A) PACT inhibits endogenous PKR and elF2a phosphorylation and increases pNL4-3 expression. HEK 293 T cells were mock transfected (lane 1), transfected with 2 $\mu \mathrm{g}$ pNL4-3 (lanes 2-5) and 0.5 $\mu \mathrm{g}$ (lane 3), $1.0 \mu \mathrm{g}$ (lane 4) or $1.5 \mu \mathrm{g}$ (lane 5) of pCMV2-Flag-PACT. pCMV2 was added to reach the same amount of transfected DNA. (Top) \% RT activity is the ratio between the RT level in the presence of PKR and PACT versus pNL4-3 alone normalized to $100 \%$. Shown is the average of 6 independent transfections \pm SEM. (Middle) Immunoblot of cell extracts of a representative experiment from the same transfected cells using antibodies against P-PKR, PKR, Flag, HIV-1 p24, P-elF2a, elF2a and actin. (Bottom) Ratio of phosphorylated PKR (P-PKR) versus PKR and P-elF2a versus elF2a. The band intensity was digitalized using Adobe Photoshop software from the bands shown above. P-PKR /PKR and P-elF2a/elF2a ratio was calculated by dividing the P-PKR or P-elF2a intensity by the total PKR or elF2a intensity of each band. B) PACT

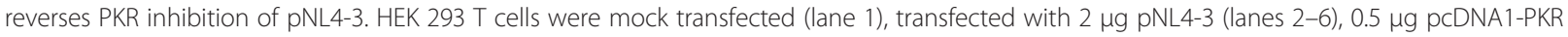
(lanes 3-6), $0.5 \mu \mathrm{g}$ (lane 4), $1.0 \mu \mathrm{g}$ (lane 5) or $1.5 \mu \mathrm{g}$ (lane 6) of pCMV2-Flag-PACT. Empty corresponding plasmids were added to reach the same amount of transfected DNA. (Top) \% RT activity is calculated as in A). Shown is the average of 6 independent transfections \pm SEM. (Middle) Immunoblot of cell extracts of a representative experiment from the same transfected cells using the same antibodies as in A). (Bottom) Ratio of phosphorylated PKR versus PKR and P-elF2a versus elF2a. The band intensities were calculated as in A).

Whereas both shRNAs PACT induced a modest increase of PKR phosphorylation, the shRNA ADAR1 consistently enhanced it. A combination of shRNA2 PACT and shRNA
ADAR1 for the same final amount resulted in an intermediate effect on viral production compared to the two shRNAs alone (Figure 5, lane 5 compared to lanes 3 and 


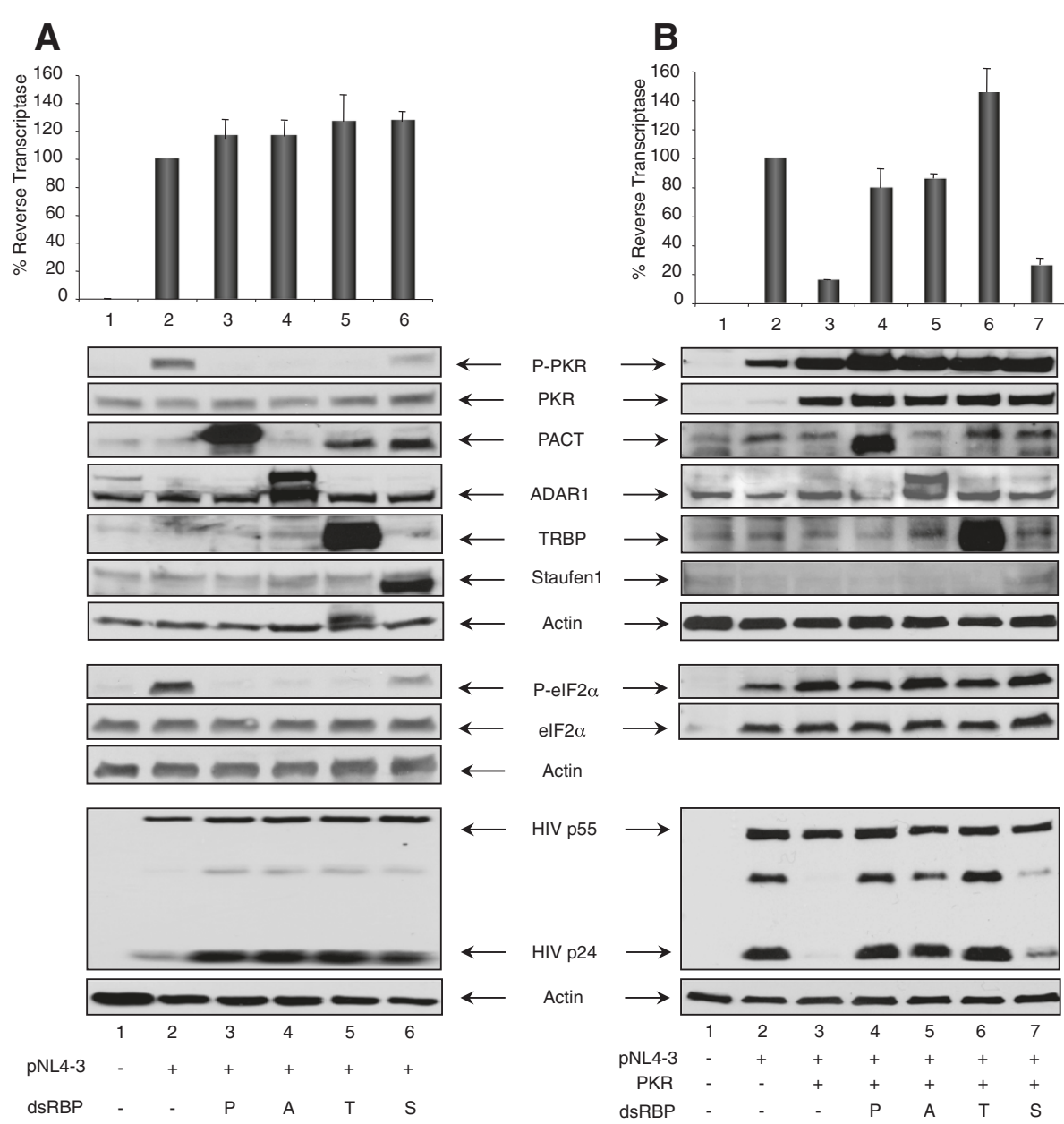

Figure 4 PACT, ADAR1 and TRBP inhibit PKR activation in HIV-1 producing cells. A) PACT, ADAR1 and TRBP, but not Staufen1, inhibit PKR and elF2a phosphorylation. HEK 293T cells were mock transfected (lane 1), transfected with $2 \mu \mathrm{g}$ pNL4-3 (lanes 2-6), and $1.5 \mu \mathrm{g}$ of pCMV2-Flag-PACT (lane 3), pcDNA3.1-ADARp150-V5 (lane 4), pcDNA3-TRBP2 (lane 5) or pCMV-RSV-Staufen1-HA (lane 6). pcDNA3 was added to reach the same amount of transfected DNA. (Top) RT activity from cell supernatants normalized to $100 \%$ in the absence of PKR or dsRBPs. Shown is the average of 6 independent transfections \pm SEM. (Bottom) Immunoblot of $150 \mu \mathrm{g}$ of cell extract of a representative experiment from the same transfected cells using antibodies against P-PKR, PKR, P-elF2a, elF2a, PACT, ADAR1, TRBP, Staufen1, HIV-1 p24 and actin as indicated. Probing for P-elF2 $a$ and elF2a were performed on a separate membrane and the corresponding actin is shown. B) PACT, ADAR1 and TRBP, but not Staufen1, restore PKR inhibition of HIV-1 protein expression and virion production. HEK 293T cells were mock transfected (lane 1), transfected with $2 \mu \mathrm{g}$ pNL4-3 (lane 2-7), $0.5 \mu \mathrm{g}$ pCDNA1-PKR (lanes 3-7) and $1.5 \mu \mathrm{g}$ of pCMV2-Flag-PACT (lane 4), pcDNA3.1-ADARp150-V5 (lane 5), pcDNA3-TRBP2 (lane 6) or pCMV-RSV-Staufen1-HA (lane 7). The empty pCMV2 vector was used to supplement transfections such that the same amount of DNA was transfected into each well. (Top) \% RT activity is calculated as in A). Shown is the average of 6 independent transfections \pm SEM. (Bottom) $150 \mathrm{\mu g}$ of each cell extract was analyzed by immunoblot against P-PKR, PKR, P-elF2a, elF2a, PACT, ADAR1, TRBP, Staufen1, HIV-1 p24 and actin as indicated. Shown is a representative experiment from the same transfected cells. Probing for P-elF2a and elF2a were performed on the same membrane as HIV-1 p24 and have the same actin.

4), suggesting an additive effect. In agreement with the data with PACT overexpression, these results suggest that in these cells, PACT contributes to the enhanced HIV-1 protein production in combination with other proteins.

\section{PACT is a PKR inhibitor in HIV-1 transfected U251MG astrocytic cells}

We next wanted to determine if the function of PACT as a PKR inhibitor during HIV-1 replication in lymphocytes as well as in HIV-1 production in HEK 293T cells could be due to TRBP heterodimers formation [18]. To do this, we evaluated PACT's activity in U251MG astrocytic cells which naturally express low levels of TRBP. We first confirmed that Flag-PACT activates PKR in astrocytes and induces eIF $2 \alpha$ phosphorylation as previously shown [18]. We also verified the activity of PACT $\triangle 13$ (also called PACT305 or PACT 1 ), a truncated PACT lacking 13 amino acids in its $\mathrm{C}$-terminus that constitutively activates PKR and is poorly sensitive to TRBP inhibition. Similar to previous results [18], PACT and PACT 13 induced PKR 


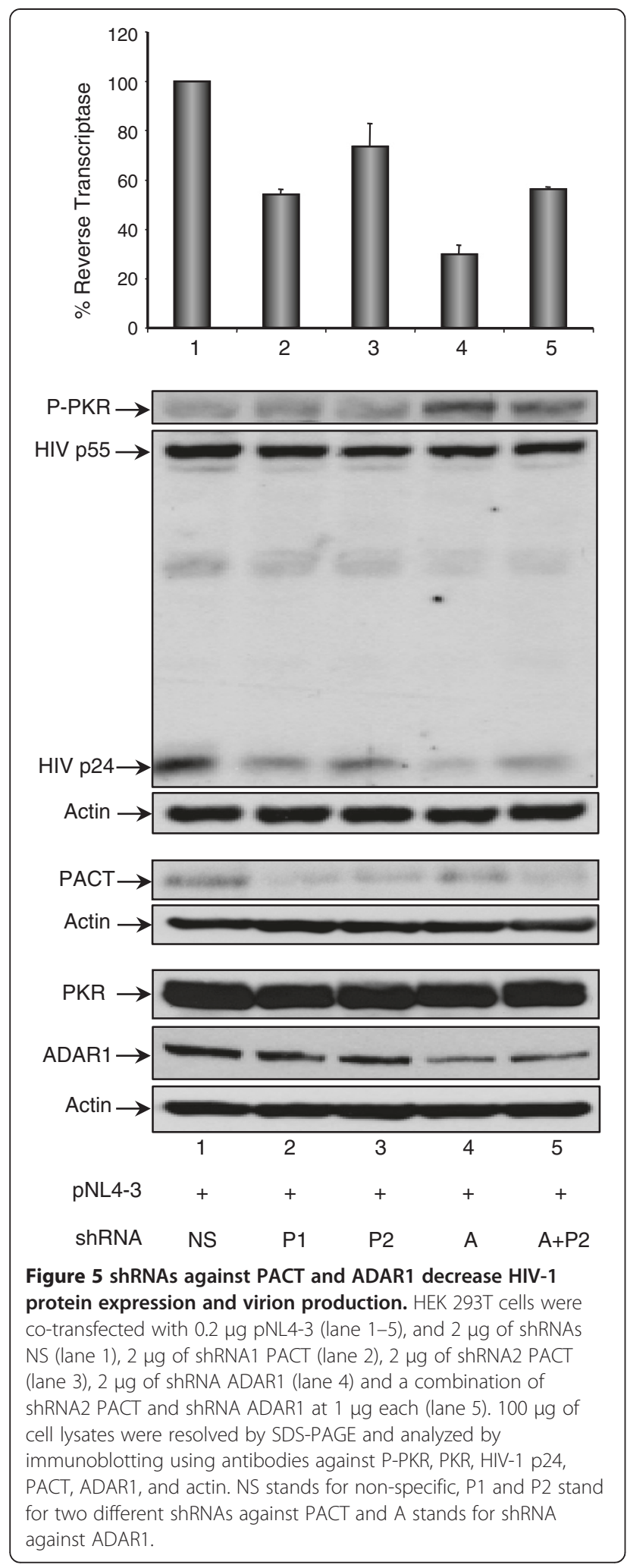

and eIF2 $\alpha$ phosphorylation with PACT $\Delta 13$ being highly active at low doses (Figure 6A). We then repeated the experiment in U251MG cells expressing HIV-1 proteins.
Indeed, if PACT is a PKR activator in astrocytes expressing HIV-1 like in Figure 6A, it could be ascribed to the lack of TRBP-PACT heterodimer formation $[18,20,55]$. In contrast, if PACT is a PKR inhibitor in these cells, the effect would not solely be due to TRBP. We observed that overexpression of PACT in HIV-transfected U251MG astrocytoma cells induced an increased expression of HIV-1 protein production and inhibited PKR and eIF2 $\alpha$ phosphorylation (Figure 6B). This result shows that PACT becomes a PKR inhibitor in astrocytes when these cells express HIV-1 proteins. The low level of HIV-1 virion production was increased by up to 4-fold, which is similar to what was previously observed with TRBP $[12,49]$. PACT $\triangle 13$ is a potent PKR activator in HIV-non-infected astrocytes ([18] and Figure 6A) and mediates apoptosis through PKR activation in HT1080 cells [61]. In U251MG cells transfected with HIV-1, we observed that PACT $\Delta 13$ lost its activating property on PKR and eIF2 $\alpha$ phosphorylation (compare Figure 6C to 6A). Compared to wild-type PACT, it lost the enhancement in HIV-1 protein expression and virion production (compare Figure $6 \mathrm{C}$ to $6 \mathrm{~B}$ ).

\section{PACT and ADAR1 directly interact in cells}

The experiments in Figure 6 demonstrate that TRBPPACT interaction cannot solely explain the change in PACT function in HIV-1 expressing cells. We therefore wanted to determine if this change could be due to a virally-induced mechanism. Because we showed that ADAR1 expression is induced during HIV-1 replication both in a lymphocytic cell line [12] and in PBMCs (Figure 1), we tested if ADAR1 and PACT could interact directly in cells. We transfected HEK 293T cells with either Flag-PACT or ADAR1 p150-V5, immunoprecipitated respectively with anti-Flag or anti-V5 antibody and blotted for either the endogenous ADAR1 or PACT (Figure 7). We recovered both proteins in the immunoprecipitate with either antibody, showing an interaction (Figure 7, lanes 4). When we treated the extracts with Benzonase, which contains RNAses against ss and dsRNAs, we clearly recovered ADAR1 with an anti-Flag showing an interaction between ADAR1 and PACT in the absence of RNA. The reverse IP with Benzonase was not as distinct, but also showed a likely direct interaction. Taken together, these results show that ADAR1 binds to PACT with or without RNAs, which could explain the reversal of PACT's function in HIV-1 producing cells.

\section{Discussion}

During HIV-1 infection, IFN $\alpha / \beta$ is mainly produced by plasmacytoid dendritic cells and acts on infected cells, but this cell response is not sufficient to clear the virus in patients [62]. Our results show that PBMCs do respond to IFN by producing IFN-stimulated genes (ISGs) and inhibiting HIV-1 replication (Figure 1). Therefore, 


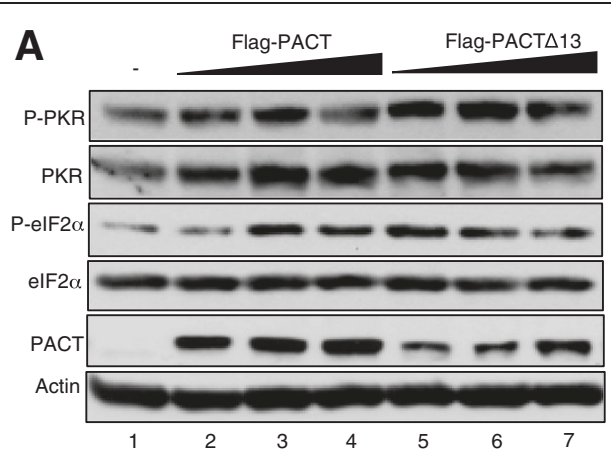

B

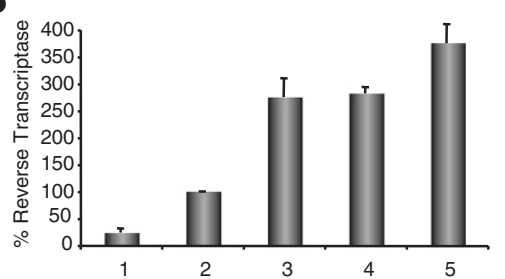

C
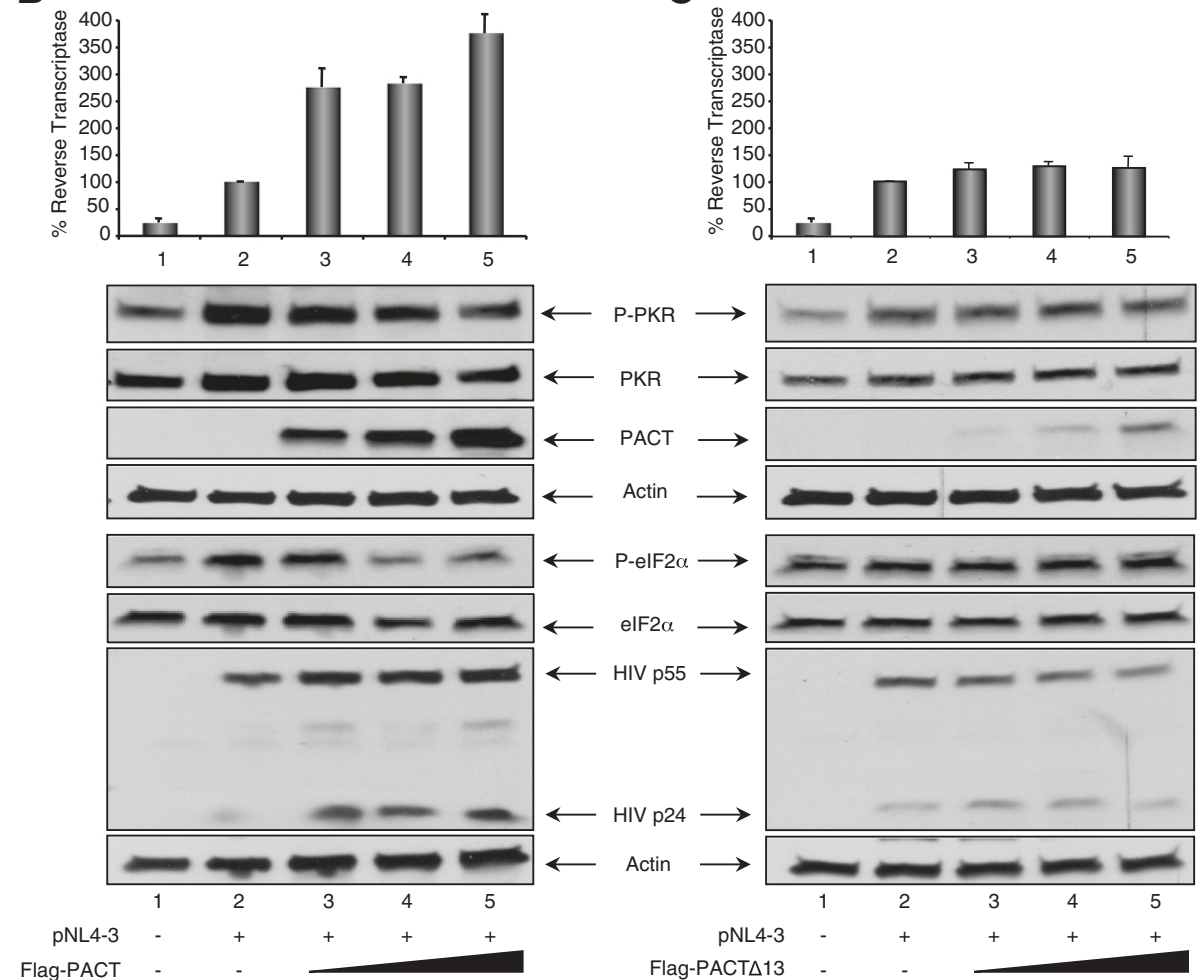

Figure 6 PACT and PACT 13 are not PKR activators in HIV-producing U251MG astrocytes. A) PACT and PACT 13 activate PKR and elF2a in U251MG astrocytes. U251MG astrocytes were mock transfected (lane 1), transfected with $0.5 \mu \mathrm{g}$ (lane 2 and 5), $1 \mu \mathrm{g}$ (lane 3 and 6), $2 \mu \mathrm{g}$ (lane 4 and 7) of PCMV2-Flag-PACT or PCMV2-Flag-PACT 13 as indicated. $100 \mu \mathrm{g}$ of cell lysates were resolved by SDS-PAGE and analyzed by immunoblotting using antibodies against P-PKR, PKR, HIV-1 p24, Flag and actin. B) PACT moderately inhibits PKR activation and causes an increase of HIV-1 production in U251MG astrocytes. U251MG astrocytes were mock transfected (lane 1), transfected with $2 \mu \mathrm{gg}$ pNL4-3 (lanes 2-5) and $0.5,1$ and $2 \mu \mathrm{g}$ of pCMV2-Flag-PACT (lanes 3-5). The corresponding empty plasmid, pCMV2, was supplemented to each transfection to have the same amount of DNA transfected in each well. (Top) The RT activity is displayed as a percentage of activation compared to pNL4-3 alone. Results shown are an average of 3 independent transfections \pm SEM. (Bottom) Cell extracts were immunoblotted and probed using antibodies against P-PKR, PKR, Flag, HIV-1 p24, P-elF2a, elF2a and actin. Shown is a representative experiment. C) PACT 13 affects neither PKR activation nor HIV-1 production in U251MG astrocytes. U251MG astrocytes were mock transfected (lane 1), transfected with 2 Mg pNL4-3 (lanes 2-5) and 0.5, 1 and $2 \mu \mathrm{g}$ of pCMV2-Flag-PACT13 (lanes 3-5). The corresponding empty plasmid, pCMV2, was supplemented to each transfection to have the same amount of DNA transfected in each well. (Top) The RT activity was displayed as a percentage of activation compared to pNL4-3 alone. Results shown are an average of 3 independent transfections \pm SEM. (Bottom) Cell extracts were immunoblotted and probed using antibodies against P-PKR, PKR, Flag, HIV-1 p24, P-elF2a, elF2a and actin. Shown is a representative experiment.

the lack of in vivo efficacy cannot be ascribed to a lack of cell response to IFN. It could be due to either an insufficient amount of IFN production or to a block in the downstream effects of IFN or both. IFN $\alpha / \beta$ also has adverse effects, which limits its therapeutic use [63-65], emphasizing the need to better understand the downstream effects of ISGs and their regulation in HIV-1 -infected cells. Among the ISGs, PKR and its activator PACT can either contribute to translational inhibition, proliferation arrest and apoptosis through eIF2 $\alpha, \mathrm{I}-\mathrm{kB}$ 


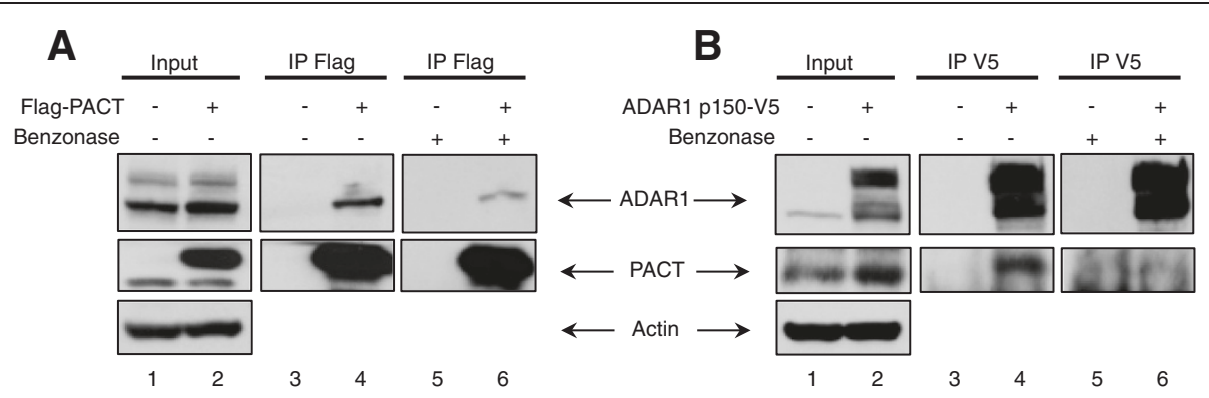

Figure 7 PACT interacts with ADAR1. A) Transfected Flag-PACT interacts with endogenous ADAR1. HEK 293T cells were not transfected (lanes 1, 3, 5), or transfected with $2 \mu \mathrm{g}$ of pCMV2-Flag-PACT (lanes 2, 4, 6). IP was performed with $2 \mathrm{mg}$ of protein and anti-Flag antibody and treated with Benzonase (lane 5, 6). $150 \mu \mathrm{g}$ of cell lysate (input or immunoprecipitates) were resolved by 10\% SDS-PAGE and analyzed by immunoblotting using antibodies against ADAR1, PACT and actin. B) Transfected ADAR1-V5 interacts with endogenous PACT. HEK 293T cells were not transfected (lanes 1, 3, 5), or transfected with $2 \mu \mathrm{g}$ of pcDNA3.1-ADARp150-V5 (lanes 2, 4, 6). IP was performed with 2 mg of protein and anti-V5 antibody and treated with Benzonase (lane 5, 6). $150 \mu \mathrm{g}$ of cell lysate (input or immunoprecipitates) were resolved by 10\% SDS-PAGE and analyzed by immunoblotting using antibodies against ADAR1, PACT and actin.

phosphorylation or IFN $\beta$ induction when PKR is activated [52-54,61,66,67], or to increased viral replication and NF$\mathrm{KB}$ signaling when it is not activated $[12,17,25,26,68]$. Because the PKR/PACT axis is part of the innate immune response to viruses, the elucidation of its activity is important to understand the inefficient response during HIV-1 replication. We and others have shown that PKR is extremely effective in restricting HIV-1 replication in vitro [12,27-30,49]. Furthermore, knocking down PKR by small interfering RNAs (siRNAs) or expressing a transdominant mutant of PKR increases HIV-1 production [49]. Despite this activity, HIV-1 replicates efficiently in many cells, suggesting that the activity of PKR in natural infection is highly regulated [17]. We therefore investigated the activation or deactivation of PKR during HIV-1 infection and the activity of exogenous IFN on PKR induction and activation. The transient activation of PKR followed by an absence of activation during HIV-1 infection of PBMCs (Figure 1) resembles the one observed with lymphocytic cell lines infected with X4 or R5 HIV-1 strains [12]. The transient activation of PKR in PBMCs suggests that this part of the innate immune response is active but is also tightly regulated during the infection of primary lymphocytes and monocytes in patients. Interestingly, the addition of IFN inhibited virus growth and induced PKR induction and activation. PKR induction was delayed by two days compared to the mock infection emphasizing that the presence of the virus postpones its expression. Furthermore, ADAR1 and PACT were induced at day 4 suggesting that an early protein from the virus may contribute to their expression.

The regulation of PKR activation is the result of the action of activators and inhibitors. The equilibrium reached after a viral infection contributes to a high or a weak cell response that will either activate innate immunity and block viral replication or let the virus replicate [32]. In the case of HIV-1 infection, the TAR RNA is likely one of the main activators of PKR at the beginning of the infection, but may become an inhibitor if produced in large amounts in the cell [69]. The HIV-1 Tat protein is also an inhibitor of PKR acting by substrate competition [31]. Besides direct viral countermeasures, viruses also evolved to replicate in cells that have the appropriate cellular components to allow their replication [70]. Viruses can also induce the production of cellular proteins that will counteract an antiviral cell response. A cell that expresses high amounts of PKR inhibitors certainly favors HIV-1 replication. HIV-1 replicates in cells that express a large amount of TRBP that inhibits PKR $[39,49]$. HIV-1 also induces ADAR1 production, which contributes to PKR inhibition and RNA editing and favors viral replication [12,50,71]. We show here that ADAR1 is also induced in PBMCs (Figure 1B), which corroborates this effect in primary cells. Because TRBP not only acts on PKR, but also prevents PACT activity on PKR $[18,55]$, we originally thought that PACT may activate PKR and that the end-up result of the PKR status would be a balance between PKR activators and PKR inhibitors. The identification of PACT in a protein complex with PKR, TRBP and ADAR1 during HIV-1 infection suggested a role for PACT but raised the question of its function within this complex (Figure 2).

When overexpressed in HIV-1-expressing cells, PACT inhibited PKR and eIF2 $\alpha$ phosphorylation and consequently increased HIV-1 expression (Figures 3 and 4). PACT inhibition of PKR activation and consequently on eIF2 $\alpha$ phosphorylation was very dramatic on endogenous PKR (Figures 3A and 4A), indicating that PACT reverses its function in HIV-1-producing cells. When PKR was overexpressed, the effect of PACT on PKR activation was only visible on the P-PKR/PKR and P- eIF2 $\alpha / \mathrm{eIF} 2 \alpha$ ratio (Figure 3B), but clearly reversed PKR inhibition of HIV-1 production, suggesting that PACT may also act through another kinase like PERK, or directly on eIF $2 \alpha$, or it 
may have an additional activity to increase viral expression. The mechanism of this increased viral expression despite high PKR phosphorylation may be related to the phosphorylation of HIV-1 Tat by PKR [72] or to a transcriptional activity of PACT similar to the recently observed recruitment of PACT, TRBP and Dicer to the promoter of nuclear receptors [73]. Furthermore, PACT inhibition by shRNAs decreased HIV-1 protein expression similarly to shRNAs against ADAR1 (Figure 5). Together, the increased expression of PACT during HIV-1 replication in PBMCs (Figure 1), the increased PKR-PACT interaction at the peak of infection (Figure 2), PACT activity upon over-expression (Figures 3 and 4) and results with shRNAs (Figure 5) contribute to reach the same conclusion that PACT is a PKR inhibitor during HIV-1 replication. There are several explanations that could explain this activity: i) TRBP is present in high amounts in HEK 293 $\mathrm{T}$ cells and forms heterodimers with all PACT molecules, which reverses PKR activation; ii) the large amount of ADAR1 induced by HIV-1 binds to PACT and reverses its function; or iii) an HIV-1 component or an HIV-induced component will change PACT from an activator into an inhibitor of PKR.

Our results in the astrocytic cells U251MG show that the first hypothesis by the formation of TRBP-PACT heterodimers cannot be the sole explanation, strongly suggesting that an HIV-1 component or an HIV-induced component mediates the change in PACT function in HIV1-expressing cells (Figure 6). This component prevents PACT from being a PKR activator and changes it into a PKR inhibitor with a similar activity as TRBP on PKR. Furthermore, PACT $\Delta 13$, although not naturally produced in cells, has been shown to be a strong activator of PKR, because it is constitutively active and not regulated by TRBP $[18,20,61]$. Its loss of activity in HIV-1-expressing astrocytes reinforces the idea that an HIV-1 or HIV-induced component reverses PACT activating function on PKR independently of TRBP (Figure 6C). The second possibility would be that the HIV-mediated increase in ADAR1 expression mediates a change in PACT function by direct binding. Our IP assays show that it may be the case because the two proteins are in the same complex during HIV-1 infection (Figure 2) and that they interact in the absence of RNA (Figure 7). We cannot exclude that another mechanism may be involved as well. PACT-Dicer interaction [74] or PACT induction of RIG-I upon Sendai virus infection [75] seems unlikely here because it would lead to viral restriction or enhanced innate immune response respectively, which we do not observe during HIV-1 infection or after PACT overexpression of HIV-1-expressing cells (Figures 1, 3, 4, 6). Therefore, ADAR1-PACT interaction is currently the most likely mechanism, which may contribute, at least in part, to the change in PACT activity during HIV-1 infection.
Our results show that three cellular proteins, TRBP, ADAR1 and PACT contribute to the inhibition of PKR and eIF2 $\alpha$ phosphorylation observed in HIV-1-infected cells (Figure 4). All of them are dsRBPs, therefore raising the question if all proteins of this family act similarly. Staufen1 was used as another dsRBP that has a positive activity on the virus by binding to Gag and by increasing translation from TAR-containing RNAs [9,76]. In agreement with its PKR-independent mechanism on translation [9], we found that Staufen1 did not inhibit PKR activation supporting a combined inhibition of PKR by TRBP, ADAR1 and PACT and a different mechanism for Staufen1 via Gag multimerization, HIV-1 assembly and encapsidation of genomic RNA [77-79], all contributing to viral replication. Further studies will determine if PKR forms a different protein complex at the beginning of HIV-1 infection when PKR and eIF2 $\alpha$ are activated, if PACT has a different activity in this context and how it may contribute to the pathogenicity induced by the virus.

\section{Conclusions}

Previous results have characterized PACT as a stressinducible PKR activator. In contrast, we show here that PACT becomes a PKR inhibitor during HIV-1 replication. PACT belongs to a multiprotein complex including the PKR inhibitors TRBP and ADAR1 formed around PKR during high viral replication. Results strongly suggest that PACT reversion of PKR activation comes in addition to its control by TRBP and could be due to its interaction with ADAR1 and other HIV-1 or an HIV-induced component. These data show that HIV-1 has evolved using several mechanisms to overcome the innate cell response.

\section{Methods}

\section{Cells and transfections}

HEK 293T (ATCC CRL-11268) and U251MG [49] cells were maintained at $37^{\circ} \mathrm{C}$ in $5 \% \mathrm{CO}_{2}$ in Dulbecco's modified Eagle's Medium (DMEM; Invitrogen) supplemented with 10\% fetal bovine serum (HyClone), $2 \mathrm{mM}$ L-glutamine, and 1\% penicillin-streptomycin (Invitrogen). Jurkat $\mathrm{T}$ cells (ATCC TIB-152) were maintained in RPMI-1640 (Invitrogen) supplemented similarly.

Peripheral blood mononuclear cells (PBMCs) were obtained from healthy donors previously selected to be negative for HIV, HTLV-I and II, HCV, CMV and syphilis. Blood sample collection was approved by the ethics review board of McGill University.

For transfection of HEK 293T and U251MG cells with plasmids, cells were plated in six-well plates at $50 \%$ confluence $24 \mathrm{~h}$ prior to transfection using polyethylenimine (PEI) following manufacturer's protocol (Polysciences). Transfection of HEK 293T cells with shRNA vectors $(2 \mu \mathrm{g} /$ well in a 6-well plate) was performed $24 \mathrm{~h}$ after plating using TransIT-LT (Mirus) as described [80]. pNL4-3 
$(0.2 \mu \mathrm{g} /$ well in a 6-well plate) was then transfected using TransIT-LT $24 \mathrm{~h}$ after transfection of the shRNAs. Supernatants and lysates were then collected $48 \mathrm{~h}$ after transfection of pNL4-3 as described [81].

\section{Plasmids and shRNA synthesis}

HIV-1 clone pNL4-3, pcDNA1-PKR, pCMV2-FlagPACT, pCMV2-Flag-PACT $\Delta 13$, pcDNA3-TRBP2, pcDNA3.1-ADARp150-V5, and pcDNA3-RSV-Staufen1HA were previously described $[12,55,82]$.

shRNAs targeting PACT and ADAR1 were cloned into the psiRNA vector (InvivoGen) using sequences obtained from the Sigma-Aldrich website. The sense (S) and antisense (AS) oligonucleotide sequences of the shRNAs are:

PACT 1: (S) 5' -

ACCTCGCGCCAATGGACAATATCAATCTCGA

GATTGATATTGTCCATT GGCGCTT - 3' and (AS) 5' CAAAAAGCGCCAATGGACAATATCAATCTC

GAGATTGATATTGTCC ATTGGCGCG - 3'.

PACT 2: (S) 5' -

ACCTCGCGCCAATGGACAATATCAATACTCGAG

AATTGATATTGTCCATT

GG'CGCTT- 3' and (AS) 5' -

CAAAAAGCGCCAATGGACAATATCAATTCTC

GAGTATTGATATTGTCCATTGGCGCG - 3'.

ADAR $1:(S) 5^{\prime}-$

ACCTCGCTGTTAGAATATGCCCAGTTACTCGA

GAAACTGGGCATATTCTA

ACAGCTT- 3' and (AS) 5' -

CAAAAAGCTGTTAGAATATGCCCAGTTTC

TCGAGTAACTGGGCATATTCTAACAGCG - 3'.

After annealing at $80^{\circ} \mathrm{C}$ for 2 minutes, the shRNAs were ligated into BbsI-digested psiRNA.

\section{Transfection of HIV-1 molecular clones and RT assay}

HEK 293T were transfected as above with pNL4-3 proviral DNA. Cell supernatants were collected $48 \mathrm{~h}$ post transfection and viral production assayed for standard RT assay. RT assay was as previously described [81] with modifications described in [83]. Supernatants from transfected HEK $293 \mathrm{~T}$ cells were used for infection of Jurkat or PBMCs.

The RT assay from the supernatant of transfected U251MG cells was carried out in a similar manner, with the exception of a longer incubation period at $37^{\circ} \mathrm{C}(3 \mathrm{~h})$ and $10 \mu \mathrm{l}$ being spotted onto the DEAE paper as previously [84]. This was to account for the low amount of virus production in $\mathrm{U} 251 \mathrm{MG}$ astrocytes.
HIV-1 viral infection of Jurkat cells and PBMCs

HIV-1 Jurkat cells infection was previously described [12]. For PBMCs HIV-1 infection, cells were stimulated with $0.6 \mu \mathrm{g} / \mathrm{ml}$ phytohaemagglutinin (Sigma cat. \# 12646) for three days in supplemented RPMI (Invitrogen). $24 \mathrm{~h}$ prior to infection, recombinant human interleukin 2 (IL-2) (R\&D Systems, cat. \# 202-IL) was added to the cells for a final concentration of $10 \mathrm{ng} / \mathrm{ml}$. $6.5 \times 10^{7}$ cells were infected with HIV-1 cell supernatant corresponding to $1.3 \times 10^{7} \mathrm{cpm}$ measured by standard RT assay in a final volume of $2.5 \mathrm{ml}$ supplemented RPMI in polypropylene round-bottom tube, and incubated for $2 \mathrm{~h}$ at $37^{\circ} \mathrm{C}$. RPMI supplemented with IL-2 for a final concentration of $10 \mathrm{ng} / \mathrm{ml}$ was then added to the cell-virus mixture, transferred to a T25 flask and incubated at $37^{\circ} \mathrm{C}$. The cells were fed on average every two days with fresh medium supplemented with IL-2 (10 ng/ml). Supernatant and cell samples were collected at different times and assayed for RT activity, immunoblotting and IP when indicated.

\section{Immunoprecipitation and immunoblotting}

IP with infected Jurkat cells was previously described [12]. For IP from HEK 293T cells, 48 h post-transfection, cells were washed twice with PBS and lysed in the cold lysis buffer with protease inhibitors. For each IP, $50 \mu \mathrm{l}$ of protein $G$ agarose fast flow compact beads (Sigma) were washed with TNEN (50 mM Tris- $\mathrm{HCl}$ [pH 7.4], $100 \mathrm{mM}$ $\mathrm{NaCl}, 1 \mathrm{mM}$ EDTA [pH 8], 0.5\% NP40 (Sigma)) and left rotating at $4^{\circ} \mathrm{C}$ for overnight incubation at $4^{\circ} \mathrm{C}$ with $5 \mu \mathrm{g}$ of anti-V5 antibody (Invitrogen). $500 \mu \mathrm{g}$ to $2 \mathrm{mg}$ of cell extract was added to the beads for overnight incubation at $4^{\circ} \mathrm{C}$. The beads were washed 3 times with $1 \mathrm{ml}$ of cold lysis buffer, 5 times with $1 \mathrm{ml}$ cold PBS and resuspended in SDS loading dye. When indicated, the beads were treated with $250 \mathrm{U} / \mathrm{ml}$ of Benzonase ${ }^{\varpi}$ (Sigma) in $50 \mathrm{mM}$ Tris$\mathrm{HCl}, 1 \mathrm{mM} \mathrm{MgCl} 2, \mathrm{pH} 8.0$ for $30 \mathrm{~min}$ at $37^{\circ} \mathrm{C}$. Bound proteins were eluted by boiling the beads for $5 \mathrm{~min}$ and separated by $10 \%$ SDS-PAGE. The immunoprecipitates were analyzed by a Western blot analysis using the antiADAR1 (from Dr. BL Bass) or anti-PACT (Medimabs) antibodies.

For immunoblotting, HEK 293T, or Jurkat T cells extracts were prepared, separated and transferred on a Hybond ECL nitrocellulose membrane (GE Healthcare) as previously described [55]. Membranes were blocked for $1 \mathrm{~h}$ in $5 \%$ nonfat dry milk and Tris-buffered saline- $0.1 \%$ Tween 20 (TBST). Membranes were incubated overnight at $4^{\circ} \mathrm{C}$ with the primary antibody. After five washes in TBST, membranes were incubated with Horseradish Peroxidaseconjugated secondary goat anti-rabbit or goat anti-mouse antibody (GE Healthcare). Anti-P-PKR (Abcam) and antiP-eIF2 $\alpha$ (Invitrogen) was blotted in 3\% BSA/TBST overnight. After immunoblotting with an antibody, the membranes were washed in TBST overnight or stripped 
and reused to detect other proteins. The bands were visualized using ECL (GE Healthcare). Primary antibodies used for immunoblotting were: monoclonals anti-PKR 71-10 [85] obtained from Dr. A. Hovanessian, anti-Actin (Chemicon) at a 1/5000 dilution, anti-HIVp24 183-H12-5C [86], at a $1 / 1000$ dilution, anti-Flag (Sigma) at a $1 / 5000$ dilution, polyclonal anti-TRBPjbx [18] at a 1/500 dilution, anti-P-PKR (Abcam), anti-PACT (Medimabs), anti-Staufen1, anti-ADAR1, anti-P-eIF2 $\alpha$ (Invitrogen) and anti-eIF2 $\alpha$ (Cell Signaling), at a 1/1000 dilution. The anti-Staufen 1 antibody was generated at the Cell Imaging and Analysis Network (McGill University, Montréal, Canada) using purified full-length His-tagged Staufen1 protein. For multiple blotting, when the same membrane cannot be blotted again, extracts from the same experiment were separated by SDS PAGE and blotted on a new membrane. In this case, actin is shown for each membrane. Where indicated, the bands where quantified by densitometry analysis as described [80].

\section{Abbreviations}

HIV-1: Human immunodeficiency virus type 1; PKR: Protein kinase RNA-activated; elF2a: Alpha subunit of the eukaryotic translation initiation factor 2; IFN: Interferon; dsRBP: Double-stranded RNA binding protein; dsRBD: Double-stranded RNA binding domain; ADAR1: Adenosine deaminase acting on RNA 1; TRBP: TAR RNA binding protein; PACT: PKR activator; PBMCs: Peripheral blood mononuclear cells; siRNA: Small interfering RNA; shRNA: Short hairpin RNA; RT: Reverse transcriptase; IP: Immunoprecipitation.

\section{Competing interests}

The authors declare that they have no competing interests.

\section{Authors' contributions}

The work was originally designed by GC, JFG and AG, followed by ES, AD, SB, TE, LS and AG. GC, ES, AD, SB, JFG, TE and LS performed the experiments and analyzed the corresponding data. JPR, AJM, RCP provided reagents and analyzed data. AG has supervised all the work and wrote the final version. All authors have participated to the writing and have approved the final version.

\section{Acknowledgements}

We would like to thank Dr. Mohammed-Rachid Boulassel for access to selected tissue samples, Dr. Eliane Meurs for helpful discussions, Sylvanne Daniels and Robert Scarborough for comments on the manuscript and Dr. Brenda L Bass' laboratory for the gift of the ADAR1 antibody. This work was supported in parts by grants HOP93434 and HOP103229 from the Canadian Institutes for Health Research (CIHR) (to AG), by grant HOP103230 from CIHR (to JPR), by the Réseau-SIDA Maladies Infectieuses from the Fond de la Recherche du Québec en Santé (FRQ-S) (to JPR), by grant MOP38111 from CIHR (to AJM). ES was supported by a Gerald Clavet fellowship from the faculty of Medicine, McGill University. SB is supported by a Masters fellowship from FRQ-S and TE by a post-doctoral fellowship HFE-113185 from $\mathrm{CIHR}$

\section{Author details}

${ }^{1}$ Lady Davis Institute for Medical Research, 3999 Côte Ste Catherine, Montréal, QC H3T 1E2, Canada. ²Department of Medicine, Division of Experimental Medicine McGill University, Montréal, Québec, Canada. ${ }^{3}$ Depatment of Microbiology \& Immunology, McGill University, Montréal, Québec, Canada. ${ }^{4}$ Chronic viral IIIness Service and Division of Hematology, McGill University Health Centre, Montréal, Québec, Canada. ${ }^{5}$ Department of Biological Sciences, University of South Carolina, Columbia, SC, USA. ${ }^{6}$ Present address: Radiation Oncology Department, Jewish General Hospital, Montréal, Canada. ${ }^{7}$ Present address: Gene Medicine research group, John Radcliffe Hospital, University of Oxford, Oxford, UK
Received: 5 October 2012 Accepted: 6 September 2013

Published: 11 September 2013

\section{References}

1. Bolinger C, Boris-Lawrie K: Mechanisms employed by retroviruses to exploit host factors for translational control of a complicated proteome. Retrovirol 2009, 6:8.

2. Gatignol A: Transcription of HIV: Tat and cellular chromatin. Adv Pharmacol 2007, 55:137-159.

3. McLaren M, Marsh K, Cochrane A: Modulating HIV-1 RNA processing and utilization. Front Biosci 2008, 13:5693-5707.

4. Anderson JL, Johnson AT, Howard JL, Purcell DF: Both linear and discontinuous ribosome scanning are used for translation initiation from bicistronic human immunodeficiency virus type 1 env mRNAs. J Virol 2007, 81:4664-4676

5. Brasey A, Lopez-Lastra M, Ohlmann T, Beerens N, Berkhout B, Darlix JL, Sonenberg $\mathrm{N}$ : The leader of human immunodeficiency virus type 1 genomic RNA harbors an internal ribosome entry segment that is active during the G2/M phase of the cell cycle. J Virol 2003, 77:3939-3949.

6. Charbonneau J, Gendron K, Ferbeyre G, Brakier-Gingras L: The 5' UTR of HIV-1 full-length mRNA and the Tat viral protein modulate the programmed -1 ribosomal frameshift that generates HIV-1 enzymes. RNA 2012, 18:519-529.

7. Bannwarth S, Gatignol A: HIV-1 TAR RNA: the target of molecular interactions between the virus and its host. Curr HIV Res 2005, 3:61-71.

8. Dorin D, Bonnet MC, Bannwarth S, Gatignol A, Meurs EF, Vaquero C: The TAR RNA-binding protein, TRBP, stimulates the expression of TAR-containing RNAs in vitro and in vivo independently of its ability to inhibit the dsRNA-dependent kinase PKR. J Biol Chem 2003, 278:4440-4448,

9. Dugré-Brisson S, Elvira G, Boulay K, Chatel-Chaix L, Mouland AJ, DesGroseillers L: Interaction of Staufen 1 with the $5^{\prime}$ end of mRNA facilitates translation of these RNAs. Nucleic Acids Res 2005, 33:4797-4812.

10. Gendron K, Charbonneau J, Dulude D, Heveker N, Ferbeyre G, Brakier-Gingras L: The presence of the TAR RNA structure alters the programmed -1 ribosomal frameshift efficiency of the human immunodeficiency virus type 1 (HIV-1) by modifying the rate of translation initiation. Nucleic Acids Res 2008, 36:30-40.

11. Chang YN, Kenan DJ, Keene JD, Gatignol A, Jeang KT: Direct interactions between autoantigen La and human immunodeficiency virus leader RNA. J Virol 1994, 68:7008-7020.

12. Clerzius G, Gélinas JF, Daher A, Bonnet M, Meurs EF, Gatignol A: ADAR1 interacts with PKR during human immunodeficiency virus infection of lymphocytes and contributes to viral replication. J Virol 2009, 83:10119-10128.

13. Daniels SM, Gatignol A: The multiple functions of TRBP, at the Hub of cell responses to viruses, stress, and cancer. Microbiol Mol Biol Rev 2012, 76:652-666.

14. Gatignol A, Buckler-White A, Berkhout B, Jeang KT: Characterization of a human TAR RNA-binding protein that activates the HIV-1 LTR. Science 1991, 251:1597-1600.

15. Gélinas JF, Clerzius G, Shaw E, Gatignol A: Enhancement of replication of RNA viruses by ADAR1 via RNA editing and inhibition of RNA-activated protein kinase. J Virol 2011, 85:8460-8466.

16. Christensen HS, Daher A, Soye KJ, Frankel LB, Alexander MR, Lainé S, Bannwarth S, Ong CL, Chung SW, Campbell SM, Purcell DF, Gatignol A: Small interfering RNAs against the TAR RNA binding protein, TRBP, a dicer cofactor, inhibit human immunodeficiency virus type 1 long terminal repeat expression and viral production. J Viro/ 2007, 81:5121-5131.

17. Clerzius G, Gélinas JF, Gatignol A: Multiple levels of PKR inhibition during HIV-1 replication. Rev Med Virol 2011, 21:42-53.

18. Daher A, Laraki G, Singh M, Melendez-Peña CE, Bannwarth S, Peters AH, Meurs EF, Braun RE, Patel RC, Gatignol A: TRBP control of PACT-induced phosphorylation of PKR is reversed by stress. Mol Cell Biol 2009, 29:254-265.

19. Daher A, Longuet M, Dorin D, Bois F, Segeral E, Bannwarth S, Battisti PL, Purcell DF, Benarous R, Vaquero C, Meurs EF, Gatignol A: Two dimerization domains in the trans-activation response RNA-binding protein (TRBP) individually reverse the protein kinase R inhibition of HIV-1 long terminal repeat expression. J Biol Chem 2001, 276:33899-33905.

20. Singh M, Castillo D, Patel CV, Patel RC: Stress-induced phosphorylation of PACT reduces its interaction with TRBP and leads to PKR activation. Biochemistry 2011, 50:4550-4560.

21. Dabo S, Meurs EF: dsRNA-dependent protein kinase PKR and its role in stress, signaling and HCV infection. Viruses 2012, 4:2598-2635. 
22. García MA, Gil J, Ventoso I, Guerra S, Domingo E, Rivas C, Esteban M: Impact of protein kinase PKR in cell biology: from antiviral to antiproliferative action. Microbiol Mol Biol Rev 2006, 70:1032-1060.

23. Meurs E, Chong K, Galabru J, Thomas NS, Kerr IM, Williams BR, Hovanessian AG: Molecular cloning and characterization of the human double-stranded RNA-activated protein kinase induced by interferon. Cell 1990, 62:379-390.

24. Sadler AJ, Williams BR: Structure and function of the protein kinase R. Curr Top Microbiol Immunol 2007, 316:253-292.

25. Bonnet MC, Daurat C, Ottone C, Meurs EF: The N-terminus of PKR is responsible for the activation of the NF-kappaB signaling pathway by interacting with the IKK complex. Cell Signal 2006, 18:1865-1875.

26. Gil J, García MA, Gomez-Puertas P, Guerra S, Rullas J, Nakano H, Alcamí J, Esteban M: TRAF family proteins link PKR with NF-kappa B activation. Mol Cell Biol 2004, 24:4502-4512.

27. Adelson ME, Martinand-Mari C, lacono KT, Muto NF, Suhadolnik RJ: Inhibition of human immunodeficiency virus (HIV-1) replication in SupT1 cells transduced with an HIV-1 LTR-driven PKR cDNA construct. Eur J Biochem 1999, 264:806-815.

28. Benkirane M, Neuveut C, Chun RF, Smith SM, Samuel CE, Gatignol A, Jeang KT: Oncogenic potential of TAR RNA binding protein TRBP and its regulatory interaction with RNA-dependent protein kinase PKR. EMBO J 1997, 16:611-624.

29. Dimitrova DI, Yang X, Reichenbach NL, Karakasidis S, Sutton RE, Henderson EE, Rogers TJ, Suhadolnik RJ: Lentivirus-mediated transduction of PKR into CD34 (+) hematopoietic stem cells inhibits HIV-1 replication in differentiated T cell progeny. J Interferon Cytokine Res 2005, 25:345-360.

30. Muto NF, Martinand-Mari C, Adelson ME, Suhadolnik RJ: Inhibition of replication of reactivated human immunodeficiency virus type 1 (HIV-1) in latently infected U1 cells transduced with an HIV-1 long terminal repeat-driven PKR cDNA construct. J Virol 1999, 73:9021-9028.

31. Cai R, Carpick B, Chun RF, Jeang KT, Williams BR: HIV-I TAT inhibits PKR activity by both RNA-dependent and RNA-independent mechanisms. Arch Biochem Biophys 2000, 373:361-367.

32. García MA, Meurs EF, Esteban M: The dsRNA protein kinase PKR: virus and cell control. Biochimie 2007, 89:799-811.

33. Sadler AJ, Williams BR: Interferon-inducible antiviral effectors. Nat Rev Immunol 2008, 8:559-568.

34. Goodman AG, Smith JA, Balachandran S, Perwitasari O, Proll SC, Thomas MJ, Korth MJ, Barber GN, Schiff LA, Katze MG: The cellular protein P58IPK regulates influenza virus $m R N A$ translation and replication through a PKR-mediated mechanism. J Virol 2007, 81:2221-2230.

35. Goodman AG, Tanner BC, Chang ST, Esteban M, Katze MG: Virus infection rapidly activates the P58(IPK) pathway, delaying peak kinase activation to enhance viral replication. Virology 2011, 417:27-36.

36. Li Z, Okonski KM, Samuel CE: Adenosine deaminase acting on RNA 1 (ADAR1) suppresses the induction of interferon by measles virus. J Virol 2012, 86:3787-3794.

37. Mittelstadt M, Frump A, Khuu T, Fowlkes V, Handy I, Patel CV, Patel RC: Interaction of human tRNA-dihydrouridine synthase- 2 with interferon-induced protein kinase PKR. Nucleic Acids Res 2008 36:998-1008.

38. Nie $Y$, Hammond GL, Yang JH: Double-stranded RNA deaminase ADAR1 increases host susceptibility to virus infection. J Virol 2007, 81:917-923.

39. Sanghvi VR, Steel LF: The cellular TAR RNA binding protein, TRBP, promotes HIV-1 replication primarily by inhibiting the activation of double-stranded RNA-dependent kinase PKR. J Virol 2011, 85:12614-12621.

40. Toth AM, Devaux P, Cattaneo R, Samuel CE: Protein kinase PKR mediates the apoptosis induction and growth restriction phenotypes of C protein-deficient measles virus. J Virol 2009, 83:961-968.

41. Fasciano S, Hutchins B, Handy I, Patel RC: Identification of the heparin-binding domains of the interferon-induced protein kinase, PKR FEBS J 2005, 272:1425-1439.

42. Ito T, Yang M, May WS: RAX, a cellular activator for double-stranded RNA-dependent protein kinase during stress signaling. J Biol Chem 1999, 274:15427-15432.

43. Pataer A, Vorburger SA, Chada S, Balachandran S, Barber GN, Roth JA, Hunt KK Swisher SG: Melanoma differentiation-associated gene-7 protein physically associates with the double-stranded RNA-activated protein kinase PKR. Mol Ther 2005, 11:717-723.

44. Patel RC, Sen GC: PACT, a protein activator of the interferon-induced protein kinase, PKR. EMBO J 1998, 17:4379-4390.
45. Roh V, Laemmle A, Von Holzen U, Stroka D, Dufour JF, Hunt KK, Candinas D, Vorburger SA: Dual induction of PKR with E2F-1 and IFN-alpha to enhance gene therapy against hepatocellular carcinoma. Cancer Gene Ther 2008, 15:636-644.

46. Zhang HM, Ye X, Su Y, Yuan J, Liu Z, Stein DA, Yang D: Coxsackievirus B3 infection activates the unfolded protein response and induces apoptosis through downregulation of p58IPK and activation of CHOP and SREBP1. J Virol 2010, 84:8446-8459.

47. Bannwarth S, Lainé S, Daher A, Grandvaux N, Clerzius G, LeBlanc AC, Hiscott J, Gatignol A: Cell-specific regulation of TRBP1 promoter by NF-Y transcription factor in lymphocytes and astrocytes. J Mol Biol 2006, 355:898-910.

48. Bannwarth S, Talakoub L, Letourneur F, Duarte M, Purcell DF, Hiscott J, Gatignol A: Organization of the human tarbp2 gene reveals two promoters that are repressed in an astrocytic cell line. J Biol Chem 2001, 276:48803-48813.

49. Ong CL, Thorpe JC, Gorry PR, Bannwarth S, Jaworowski A, Howard JL, Chung S, Campbell S, Christensen HS, Clerzius G, Mouland AJ, Gatignol A, Purcell DF: Low TRBP levels support an innate human immunodeficiency virus type 1 resistance in astrocytes by enhancing the PKR antiviral response. J Virol 2005, 79:12763-12772.

50. Doria M, Neri F, Gallo A, Farace MG, Michienzi A: Editing of HIV-1 RNA by the double-stranded RNA deaminase ADAR1 stimulates viral infection. Nucleic Acids Res 2009, 37:5848-5858.

51. Doria M, Tomaselli S, Neri F, Ciafrè SA, Farace MG, Michienzi A, Gallo A: ADAR2 editing enzyme is a novel human immunodeficiency virus-1 proviral factor. J Gen Virol 2011, 92:1228-1232.

52. Patel CV, Handy I, Goldsmith T, Patel RC: PACT, a stress-modulated cellular activator of interferon-induced double-stranded RNA-activated protein kinase, PKR. J Biol Chem 2000, 275:37993-37998.

53. Bennett RL, Blalock WL, Abtahi DM, Pan Y, Moyer SA, May WS: RAX, the PKR activator, sensitizes cells to inflammatory cytokines, serum withdrawal, chemotherapy, and viral infection. Blood 2006, 108:821-829.

54. Bennett RL, Blalock WL, May WS: Serine 18 phosphorylation of RAX, the PKR activator, is required for PKR activation and consequent translation inhibition. J Biol Chem 2004, 279:42687-42693.

55. Laraki G, Clerzius G, Daher A, Melendez-Peña C, Daniels S, Gatignol A: Interactions between the double-stranded RNA-binding proteins TRBP and PACT define the Medipal domain that mediates protein-protein interactions. RNA Biol 2008, 5:92-103.

56. Singh M, Patel RC: Increased interaction between PACT molecules in response to stress signals is required for PKR activation. J Cell Biochem 2012, 113:2754-2764.

57. Gupta V, Huang X, Patel RC: The carboxy-terminal, M3 motifs of PACT and TRBP have opposite effects on PKR activity. Virology 2003, 315:283-291.

58. Huang $X$, Hutchins B, Patel RC: The C-terminal, third conserved motif of the protein activator PACT plays an essential role in the activation of double-stranded-RNA-dependent protein kinase (PKR). Biochem J 2002, 366:175-186.

59. Peters GA, Hartmann R, Qin J, Sen GC: Modular structure of PACT: distinct domains for binding and activating PKR. Mol Cell Biol 2001, 21:1908-1920.

60. Casey JL, Bergmann KF, Brown TL, Gerin JL: Structural requirements for RNA editing in hepatitis delta virus: evidence for a uridine-to-cytidine editing mechanism. Proc Natl Acad Sci USA 1992, 89:7149-7153.

61. Peters GA, Li S, Sen GC: Phosphorylation of specific serine residues in the PKR activation domain of PACT is essential for its ability to mediate apoptosis. J Biol Chem 2006, 281:35129-35136.

62. Hosmalin A, Lebon P: Type I interferon production in HIV-infected patients. J Leukoc Biol 2006, 80:984-993.

63. Diop OM, Ploquin MJ, Mortara L, Faye A, Jacquelin B, Kunkel D, Lebon P, Butor C, Hosmalin A, Barré-Sinoussi F, Müller-Trutwin MC: Plasmacytoid dendritic cell dynamics and alpha interferon production during Simian immunodeficiency virus infection with a nonpathogenic outcome. $J$ Virol 2008, 82:5145-5152.

64. Herbeuval JP, Shearer GM: HIV-1 immunopathogenesis: how good interferon turns bad. Clin Immunol 2007, 123:121-128.

65. Mandl JN, Barry AP, Vanderford TH, Kozyr N, Chavan R, Klucking S, Barrat FJ, Coffman RL, Staprans SI, Feinberg MB: Divergent TLR7 and TLR9 signaling and type I interferon production distinguish pathogenic and nonpathogenic AIDS virus infections. Nat Med 2008, 14:1077-1087.

66. Taghavi N, Samuel CE: Protein kinase PKR catalytic activity is required for the PKR-dependent activation of mitogen-activated protein kinases and 
amplification of interferon beta induction following virus infection. Virology 2012, 427:208-216.

67. Zamanian-Daryoush M, Mogensen TH, DiDonato JA, Williams BR: NF-kappaB activation by double-stranded-RNA-activated protein kinase (PKR) is mediated through NF-kappaB-inducing kinase and lkappaB kinase. Mol Cell Biol 2000, 20:1278-1290.

68. Tu YC, Yu CY, Liang JJ, Lin E, Liao CL, Lin YL: Blocking double-stranded RNA-activated protein kinase PKR by Japanese encephalitis virus nonstructural protein 2A. J Virol 2012, 86:10347-10358.

69. Maitra RK, McMillan NA, Desai S, McSwiggen J, Hovanessian AG, Sen G, Williams BR, Silverman RH: HIV-1 TAR RNA has an intrinsic ability to activate interferon-inducible enzymes. Virology 1994, 204:823-827.

70. Mouland AJ, Heveker N, Gatignol A: Virus-cell interactions. In Encyclopedia of molecular cell biology and molecular medicine. 2nd edition. Edited by Meyers RA. Weinheim, Germany: Wiley-VCH Verlag; 2005:423-484.

71. Phuphuakrat A, Kraiwong R, Boonarkart C, Lauhakirti D, Lee TH, Auewarakul P: Double-stranded RNA adenosine deaminases enhance expression of human immunodeficiency virus type 1 proteins. J Virol 2008, 82:10864-10872.

72. Endo-Munoz L, Warby T, Harrich D, McMillan NA: Phosphorylation of HIV Tat by PKR increases interaction with TAR RNA and enhances transcription. Virol J 2005, 2:17.

73. Redfern AD, Colley SM, Beveridge DJ, Ikeda N, Epis MR, Li X, Foulds CE, Stuart LM, Barker A, Russell VJ, Ramsay K, Kobelke SJ, Li X, Hatchell EC, Payne C, Giles KM, Messineo A, Gatignol A, Lanz RB, O'Malley BW, Leedman PJ: RNA-induced silencing complex (RISC) proteins PACT, TRBP, and dicer are SRA binding nuclear receptor coregulators. Proc Natl Acad Sci USA 2013, 110:6536-6541.

74. Kok KH, Ng MH, Ching YP, Jin DY: Human TRBP and PACT directly interact with each other and associate with dicer to facilitate the production of small interfering RNA. J Biol Chem 2007, 282:17649-17657.

75. Kok KH, Lui PY, Ng MH, Siu KL, Au SW, Jin DY: The double-stranded RNA-binding protein PACT functions as a cellular activator of RIG-I to facilitate innate antiviral response. Cell Host Microbe 2011, 9:299-309.

76. Chatel-Chaix L, Clément J-F, Martel C, Bériault V, Gatignol A, DesGroseillers L, Mouland AJ: Identification of Staufen in the human immunodeficiency virus type $1 \mathrm{Gag}$ ribonucleoprotein complex and a role in generating infectious viral particles. Mol Cell Biol 2004, 24:2637-2648.

77. Abrahamyan LG, Chatel-Chaix L, Ajamian L, Milev MP, Monette A, Clément J-F, Song R, Lehmann M, DesGroseillers L, Laughrea M, Boccaccio G, Mouland AJ: Novel Staufen 1 ribonucleoproteins prevent formation of stress granules but favour encapsidation of HIV-1 genomic RNA. J Cell Sci 2010, 123:369-383.

78. Chatel-Chaix L, Abrahamyan L, Frechina C, Mouland AJ, DesGroseillers L: The host protein Staufen 1 participates in human immunodeficiency virus type 1 assembly in live cells by influencing pr55Gag multimerization. J Virol 2007, 81:6216-6230.

79. Chatel-Chaix L, Boulay K, Mouland AJ, Desgroseillers L: The host protein Staufen 1 interacts with the Pr55Gag zinc fingers and regulates HIV-1 assembly via its N-terminus. Retrovirol 2008, 5:41.

80. Daniels SM, Melendez-Peña CE, Scarborough RJ, Daher A, Christensen HS, El Far M, Purcell DF, Lainé S, Gatignol A: Characterization of the TRBP domain required for dicer interaction and function in RNA interference. BMC Mol Biol 2009, 10:38

81. Lainé $S$, Scarborough RJ, Lévesque D, Didierlaurent L, Soye KJ, Mougel M, Perreault JP, Gatignol A: In vitro and in vivo cleavage of HIV-1 RNA by new SOFA-HDV ribozymes and their potential to inhibit viral replication. RNA Biol 2011, 8:343-353.

82. Wickham L, Duchaine T, Luo M, Nabi IR, DesGroseillers L: Mammalian staufen is a double-stranded-RNA- and tubulin-binding protein which localizes to the rough endoplasmic reticulum. Mol Cell Biol 1999, 19:2220-2230.

83. Scarborough RJ, Lévesque MV, Perreault J-P, Gatignol A: Design and evaluation of clinically relevant SOFA-HDV Ribozymes targeting HIV RNA. In Methods in molecular biology. USA: Humana Press. in press.

84. Battisti PL, Daher A, Bannwarth S, Voortman J, Peden KW, Hiscott J, Mouland AJ, Benarous R, Gatignol A: Additive activity between the trans-activation response RNA-binding protein, TRBP2, and cyclin T1 on HIV type 1 expression and viral production in murine cells. AIDS Res Hum Retrovi 2003, 19:767-778.

85. Laurent AG, Krust B, Galabru J, Svab J, Hovanessian AG: Monoclonal antibodies to an interferon-induced $\mathrm{Mr} 68,000$ protein and their use for the detection of double-stranded RNA-dependent protein kinase in human cells. Proc Natl Acad Sci USA 1985, 82:4341-4345.

86. Bounou S, Leclerc JE, Tremblay MJ: Presence of host ICAM-1 in laboratory and clinical strains of human immunodeficiency virus type 1 increases virus infectivity and CD4(+)-T-cell depletion in human lymphoid tissue, a major site of replication in vivo. J Virol 2002, 76:1004-1014.

doi:10.1186/1742-4690-10-96

Cite this article as: Clerzius et al: The PKR activator, PACT, becomes a PKR inhibitor during HIV-1 replication. Retrovirology 2013 10:96.

\section{Submit your next manuscript to BioMed Central and take full advantage of:}

- Convenient online submission

- Thorough peer review

- No space constraints or color figure charges

- Immediate publication on acceptance

- Inclusion in PubMed, CAS, Scopus and Google Scholar

- Research which is freely available for redistribution 